\title{
Current Issues in English-Indonesian Translation Equivalences
}

\author{
Anselmus Sudirman \\ Lecturer at the English Education Study Program of Universitas Sarjanawiyata Tamansiswa Yogyakarta, Indonesia
}

\begin{abstract}
This research articulates types of equivalences in the English-Indonesian translation involving lexical, grammatical and semantic elements. Using a mélange of concepts and examples, each type is elaborated further in the discussion section, giving rise to the transformation of messages from the source text into the target text properly. Otherwise, the translation lost is totally misleading. Accuracy and clarity of translation equivalences become a central issue to convey the messages from the source text to the target text more effectively. Regardless of producing multi-interpretable target texts, the lexical equivalence has something to do with equivalent replacements of lexicons in question. The emphasis of grammatical equivalence is on grammatical categories comprising number, person, gender, tense, and aspect, and the semantic equivalence is content-based in a sense that the source text is translated based on the intra-linguistic criteria (grammatical and semantic features) and extra-linguistic ones (situation, subject field and culture).
\end{abstract}

Keywords: translation, equivalence, lexical equivalence, grammatical equivalence, semantic equivalence

\section{Introduction}

Translation inevitably coincides with equivalences and nonequivalences. The practice of translation as coined by Duff (1998) emphasizes two underlying principles. First, translation equivalences in terms of language form and content constitute the ordering of words and ideas that should match the original texts as closely as possible. Second, the meaning of the target text should reflect the meaning of the source text accurately. In this perspective, translators attempt to establish equivalences for the purpose of readability, clarity, and accuracy of the source and target languages.

The articulation of translation focusing on the language form and content is regarded as a linguistic feature that puts into practice the analyses of lexical, grammatical, and semantic elements. In this way, the change of language form linguistically modifies the content area of the translation because the consistency for accurately delivering messages from the source text into the target text is of paramount importance.

The priority of transferring the meaning should comply with the accuracy and clarity even though translation nonequivalences cannot match the differences within both texts. An unavoidable mismatch between the source text and target texts is commonly called non-equivalence or untranslatability (Bassnett, 1988; Catford, 1965). By applying equivalence-oriented (Vinay \& Darbelnet in Leonardi, 2000) and text-centered approaches (Campbell, 1998), untranslatable or non-equivalent words and phrases can be traced from the standpoint of their lexical, grammatical and semantic features. However, the blurred translation, as a direct effect of untranslatability should be handled using a translator-approach (Campbell, 1988) that traces back the translated texts involving translators.

The translators ${ }^{e}$ involvement significantly aims to clarify strategies used in dealing with translation non-equivalences particularly the transfer of meaning from the source text into the target text. The translators ${ }^{\text {ee }}$ task, therefore, is to convey the meaning as clearly as possible by reconstructing the linguistic form of the target text. The complexity of a source text to be translated (in this instance a text on technology) is influenced by a text-bound principle (Duff, 1998) which is also called the text meaning in the context of the target language. The term text-bound contains two domains, namely (1) skills-reading that involves a comprehension on how to link the source text with the target text to achieve equivalent expressions; (2) writing which is time-consuming in hatching words or expressions.

\section{Literary Review}

\section{Translation}

Hatim and Munday (2004) define translation as (1) the process of transferring a written text from the source text into the target text, conducted by a translator, or translators in a specific socio-cultural context; (2) the written product, or the target text, which results from that process and which functions in the socio-cultural context of the target language; and (3) the cognitive, linguistic, visual and ideological phenomena which are an integral part of 1 and 2 .

Jacob (2002) adds that the translator has to adapt the message to the target audience and use only what he or she considers to be the most appropriate solution in any given situation. The ultimate aim is to communicate the message as effectively as possible. Thus, communicating the message to the target language readers is an effective solution in translating.

Thriveni (2002) criticizes this definition by arguing that translation is not simply a matter of seeking other words with similar meanings, but of finding appropriate ways of saying things in another language. Another critic, Zaky (2001) accentuates that translating in fact involves more than just finding corresponding words between two languages. Words are only minor elements in the total linguistic discourse. 


\section{International Journal of Science and Research (IJSR) \\ ISSN (Online): 2319-7064}

Index Copernicus Value (2013): 6.14 | Impact Factor (2014): 5.611

Despite, the acceptability of translation involves culture, text difficulties and linguistic facets worth considering. The absence of those factors results in generic-specific words that can become translation problems in the target language (Beekman and Callow, 1974) as described in Larson (1984): (1) the source language text may use a generic term, but the receptor language may only have a more specific term in that semantic area, and (2) the source language uses a specific term, but the receptor language only has a generic word available in the same semantic area.

Larson (1984) comments that regardless of the generic vocabulary, translation is much more than finding equivalent words that can be transferred from the source text into the target text. The source text structures must be abandoned for the natural receptor language structures without the significant loss or change of meaning. With regard to what the fact is, the translator not only pays attention to the structures, but the most important thing is how the language structures transfer messages from the source text into the target text.

In relation to that concept, today ${ }^{\text {ee }}$ translation quality depends on the translators ${ }^{\text {ee }}$ competence to create as many equivalent words as possible. Roberts, as stated in (Ma"emur, 2005), mentions five competencies translators must possess, namely (1) linguistic competence, i.e., the ability to understand the source language and produce acceptable target expressions, (2) translation competence, i.e., the ability to comprehend the meaning of source text and express it in the target text, (3) methodological competence, i.e., the ability to research a particular subject and to select appropriate terminologies, (4) disciplinary competence, i.e., the ability to translate texts in the same basic disciplines such as economics, information science and law, and (5) technical competence, i.e., the ability to use aids to translation like the word processor, database, and Internet.

\section{Equivalence}

In the current perspective of English language Studies, translation as a discipline of knowledge relates to double linkage equivalences (1) the linkage of words or phrases between the source text and the target text and (2) the meaning of the target text that should correspond to the meaning of source text accurately. The concept in (1) leads to lexical and grammatical elements within both texts, and the articulation of (2) is on the field of semantics that traces back the conveyance of meaning from the source language to the target language for the sake of establishing translation readability, clarity and accuracy (Duff, 1998) equivalently.

The concept of equivalence, which in turn spreads on to the notion of naturalness or proximity, can mean comparing languages in the context of cross-cultural or cross-linguistic productions (Hewson and Martin, 1991: 21). In contrast, Koller (1995) in (Hatim and Munday, 2004) highlights that translation equivalence is influenced much by a variety of potentially conflicting source language/target language linguistic textual and extra-textual factors and circumstances on the one hand and by the role of the historical-cultural conditions on the other hand under which texts and their translations are produced, perceived and received.
The translation principles proposed by Duff (1989) therefore take into account: (1) translation equivalence in terms of language form and content constitute the ordering of words and ideas that should match the original source text as closely as possible; and (2) the meaning of the target text should reflect the meaning of the source text accurately. In this perspective, a translator attempts to establish equivalences pertaining to readability, clarity and accuracy of the source and target languages.

\section{Lexical Equivalence}

Larson (1984) mentions a term called "lexical equivalents" that refers to (1) concepts in the source text which are known (shared) in the receptor language, (2) concepts in the source language that which are unknown in the receptor language, and (3) lexical items in the text which are key terms, translated using a special treatment. If this is the case, lexical equivalences help translators bridge the gap between the source and target texts.

In addition, lexical equivalences are produced using a technique called transliteration, defined as the letter-by-letter rendering of the source language name or term in the target language when the two languages have distinct scripts (Hatim \& Munday, 2004). For example, the Pusat Pembinaan dan Pengembangan Bahasa promotes the use of the word "anggit" as the new equivalence of "concept." However, Indonesian writers in general and Indonesian translators in particular avoid using this new equivalence because of its unfamiliarity with the target readers. Instead, they use the old and popular transliteration "konsep" (Nababan, 2005).

\section{Grammatical and Semantic Equivalences}

Baker (1992) mentions a grammatical equivalence that affects the diversity of grammatical categories within the source language and the target language with significant changes to come across. For example, the change occurs in grammatical devices such as number, tense and aspects, person and gender. The change also occurs in the grammatical equivalence of voice. The English active voice is translated into the Indonesian passive voice.

To support Bakeres concept of grammatical equivalence, Nida (1964) as quoted in Central Institute of Indian Language (2006) categories types of equivalences: (1) a grammatical equivalence, which is classified as the equivalence at the level of form and its focus is on the form of the source text. This kind of equivalence is source textoriented, and (2) a semantic equivalence which is contentoriented by taking into account a target text in terms of linguistic criteria such as grammatical and semantic features and extra-linguistic ones like situation, subject field, target language readers, etc. Thus, translators of informative texts should primarily aim for ,semantic equivalence ${ }^{e e}$, and only then for connotative meanings and aesthetic values. In the case of expressive texts, the main concern of the translator should be to preserve aesthetic effect alongside relevant aspects of semantic content (Hatim \& Munday, 2004). 


\section{International Journal of Science and Research (IJSR) \\ ISSN (Online): 2319-7064}

Index Copernicus Value (2013): 6.14 | Impact Factor (2014): 5.611

\section{Findings and Discussions}

\section{Lexical Equivalence}

In the context of English-Indonesian translation, lexical equivalence occurs when the source language lexis of a text is replaced by equivalent target language lexis, but without the replacement of grammar (Catford, 1965). The emphasis is dual linkage concerning with the form and content of the source and target language as described in this example:

Omnipotent computer (Newsweek, July 3/July 10, 2006).

1. a.Komputer serbabisa

b.Komputer berkekuatan tanpa batas

c.Komputer serbabisa

The translation of a noun phrase omnipotent computer in (1) is in line with "equivalence at word level" (Baker, 1992), meaning that the noun phrase is translated using a direct equivalent term komputer serbabisa (the head computer precedes the adjective omnipotent) in (1a) and (1c). The lexicon computer is translated into komputer (as the effect of transliteration) lexically but equivalently, while the adjective omnipotent is translated in a similar way, as shown in (1a) and (1c), but it is translated in a different way, as indicated in (b) resulting in a semantic shift in the target language. The point is that the adjective omnipotent is translated using several words, that is, berkekuatan tanpa batas in (1b), which is called a descriptive phrase in the receptor language (Larson, 1984).

After making a lexical crosscheck, the adjective omnipotent constitutes a direct dictionary description of "having total power, able to do anything" (Oxford Advanced Learner"s Dictionary, 2010). This is an alternative step taken owing to the limited lexical equivalence of the term in a bilingual dictionary (English-Indonesian). Rather than trapping in such a lexical constraint, a monolingual dictionary (EnglishEnglish) is used as an emergent solution to create equivalences.

The translation of the noun phrase omnipotent computer covers three requirements pertaining to lexical equivalence (Larson, 1984). First, the concept omnipotent computer in the source text is known (shared) in the receptor language because of its non-literal translation komputer serbabisa in (1a and 1c). Second, the concept omnipotent computer in the source text is unknown (unshared) in the receptor language because of its literal translation komputer berkekuatan tanpa batas in (1b), which is uncommon to target language readers. The reason is that this translation is ambiguous in terms of whether the term issued here means "the unlimited power of a computer" or it becomes an issue to controvert the fact that certain computers marketing in Indonesian computer shops have limited power and capacity. Third, the lexical item, as mentioned in (1a-c), is a key term that demands a special treatment in translating it following the norms of translation that nourish the expectation of the target language readers towards translation.

In addition, some other lexical items or lexical equivalent terms in English-Indonesian translation are regarded as loan words adopted from the source language directly with or without any additional explanation as indicated in the following example.

(2) a. software

b. debit cards

c. internet (Newsweek, July 3/July 10, 2006).

The noun phrase software (2a) is left untranslated and it is translated into a noun phrase perangkat lunak resulting in what is so-called a diluted group (Hatim \& Munday, 2004) in which the whole group of words, in this case, perangkat lunak expresses a single idea software. The plural noun phrase debit cards (2b) is translated into a target language singular noun phrase kartu debit. The source language plural noun cards in (2b) is translated into the language singular noun kartu. This is called intra-system shift (Catford, 1965) whereas the source language plural noun is translated into the target language singular noun and vice versa. The source language noun internet (2c) is left untranslated because it has become a loan word in the target language.

In search of lexical equivalence, a translator can use transliteration, which is defined as the letter-by-letter rendering of a source language name or word in the target language when the two languages have distinct scripts (Hatim and Munday, 2004). The following example is an English-Indonesian transliteration:

\section{(3) a. Computer \\ b. Technology \\ c. Electronic}

Lexicons in (3a-c) are transliterated into the target language nouns komputer, teknologi and elektronik. In contrast, the lexical equivalence in terms of idioms is translated in the context of equivalence above word level (Baker, 1992) as shown in this example:
(4) a. a case in point
b. to the tune of
c. of course
d. on the other hand

These idioms are translated by considering their contexts or cultural specificities as to emphasize unified groups (Hatim $\&$ Munday, 2004) in which coherent units of two or more words express a single idea. In other words, the source language idioms, which consist of two or more words, are translated into the target language single words. For example, the idiom a case in point is translated into seumpamanya, contohnya, and misalnya; the translation of the idiom to the tune of is sebesar and berjumlah; the idiom of course is tentu saja and the idiom on the other hand is di sisi lain, namun demikian or sebaliknya all of which focus on figurative or secondary meanings.

Thus, the translation of such idioms as suggested by Baker (1992) allows variations of forms in the receptor language following the criteria: (a) replace words with another, (b) change their grammatical structures, and (c) add new words to them. Their meanings are specific to the target language culture. 


\section{International Journal of Science and Research (IJSR) \\ ISSN (Online): 2319-7064}

Index Copernicus Value (2013): 6.14 | Impact Factor (2014): 5.611

\section{Grammatical Equivalence}

Grammatical equivalence focuses on grammatical categories comprising number, person, gender, tense, and aspect (Baker, 1992 in Irmawati \& Rohani, 2005) and some closedclass items (Fromkin, 2000). They become the heart of this sub-chapter subject to the creation of equivalences.

\section{Number}

The first category is number. Fromkin (2000) defines number as the property words realize, for example, as singular or plural marking. The following example proves that number may occur between the source language and target language singular nouns:

In $a$ Japanese government video promoting its program, some vague hybrid between an omnipotent computer and $a$ $3 \mathrm{G}$ mobile phone floats mysteriously over its users (Newsweek, July 3/July 10, 2006).

(5) a. Dalam video promosi program pemerintah Jepang, paduan samar komputer serbabisa dengan telepon genggam seri $3 G$ digambarkan mengambang ajaib di udara di atas para pengguna.

b. Dalam video pemerintah Jepang yang memperomosikan program itu, hybrid yang tidak jelas antara komputer berkekuatan tanpa batas dan HP $3 G$ beredar secara misterius para para pemakainya.

c. Dalam sebuah tayangan pemerintah Jepang yang memperomosikan programnya mengenai sejumlah produk hibrida yang tak jelas antara sebuah komputer serbabisa, sebuah telepon seluler $3 G$ mengambang secara misterius di udara, di atas para penggunanya.

The indefinite articles $a$, an (suatu, sebuah) in the noun phrases $a$ Japanese government, $a 3 \mathrm{G}$ mobile phone and an omnipotent computer are not translated in $(5 a \& 5 b)$. The absence of such articles in the translation results in the grammatical non-equivalence, but the meaning of the source language message conveyed is acceptable. The reason is that the translation of articles is "optional" (Baker, 1992). Conversely, the articles $a$ and $a n$ are translated into the target language classifier sebuah (5c) in the phrases sebuah tayangan pemerintah Jepang, sebuah komputer serbabisa and sebuah telepon seluler $3 G$ resulting from a literal translation.

Another article that needs to be analyzed is the, as illustrated in the example below:

He didn 't get the joke, of course (Newsweek, July 3/July 10, 2006).

(6) a. Tentu saja, dia tidak menangkap maksud lulecon tersebut.

b. Tentu saja dia tidak memahami lulecon itu.

c. Tentu saja ia tidak menanggapi ocehanku itu.

The definite article the in the noun phrase the joke emphasizes the specificity of a thing (Frank, 1972). The noun phrase the joke meaning the specific joke was translated into the terms lulecon tersebut (6a) and lulecon itu (6b). Thus, the translation of the article the into the target language tersebut and itu (6a-c) marks the specific meaning of the article in forming the translation equivalence.

Number in this case also deals with an intra-system shift in which a source language singular noun is translated into a target language plural noun (Catford, 1965), as indicated in this example:

Every city in South Korea seems to have a program of its own (Newsweek, July 3/July 10, 2006).

\section{(7) a. Kota-kota di Korea Selatan memiliki program tersendiri dalam konteks u-technology. \\ b. Setiap kota di Korea Selatan tampaknya memiliki program sendiri. \\ c. Setiap kota di Korea Selatan nampaknya memiliki program sendiri.}

The indefinite determiner every attached to a singular countable noun in the noun phrase every city is translated into a plural form kota-kota (cities) in (7a). The change of form in this translation does not influence the meaning of the source text since a source language singular noun can be translated into a target language plural noun. However, the target language singular form setiap kota (7b-c) links with the source language singular form every city.

The translation from a source language plural noun into a target language singular noun is important to take into account, as shown in the example below:

Sending out alerts when groceries in the refrigerator back home need replenishing (Newsweek, July 3/July 10, 2006).

(8) a. Memberi peringatan kalau stok bahan makanan di kulkas di rumah perlu diisi lagi.

b. Mengeluarkan sinyal ketika grosir kulkas perlu diisi lagi. c. Mengirim pesan ketika akulkas di rumah butuh diisi lagi.

The plural noun alerts is composed of a singular noun alert and the inflection $-s$ in a plural noun alerts. Importantly, alert and alerts are of the same class because both of them belong to the same entity - a warning of danger, of problem, but they are different in number. The plural noun alerts is translated into the target language singular noun peringatan (8a) and sinyal (8b) and pesan (8c). The translation in (8a-b) is acceptable in the target language culture because of the intra-system shift (Catford, 1965) whereas the source language plural noun can be translated into the target language singular, but the translation in (8c) is ambiguous semantically because the target language singular noun pesan (message) violates the meaning of the original noun alerts (peringatan, sinyal).

The translation from a source language plural noun into a target language plural noun is described in the following example:

Disappointing expectations, on the other hand, might not be a bad thing (Newsweek, July 3/July 10, 2006). 


\section{International Journal of Science and Research (IJSR) \\ ISSN (Online): 2319-7064}

Index Copernicus Value (2013): 6.14 | Impact Factor (2014): 5.611

(9)a. Harapan-harapan utopis yang bisa mengecewakan mungkin bukan hal negatif.

b. Di sisi lain, harapan-harapan yang mengecewakan barangkali bukanlah sesuatu yang buruk.

c. Sebaliknya, ekspektasi-ekspektasi mengecewakan perlu juga dipikirkan.

The source language plural noun expectations formed by a singular noun expectation and the inflection $-s$ is translated into the target language plural noun harapan-harapan (9a-b) and ekspektasi-ekspektasi (9c) using a singular form harapan or ekspektasi and a reduplication separated by a hyphen (a word boundary).

\section{Person and Gender}

Person and gender in this sense is limited to the translation of pronouns that are anaphoric or the use of a word referring back to a word used earlier in a text to avoid unimportant repetitions (Frank, 1972). Larson (1984) points out that the translator must have an adequate understanding of the extended usages of pronouns in the text. Otherwise, the proclivity of creating translation non-equivalence is unavoidable. Notice the following example:

What weell see in the years to come is computers disappearing into devices being imbedded everywhere (Newsweek, July 3/July 10, 2006).

(10) a. Yang terjadi pada tahun-tahun mendatang adalah hilangnya komputer-komputer yang sekarang ada karena tergantikan dengan sarana-sarana teknologi baru yang dipasang berjaring dan terintegral di berbagai tempat.

b. Apa yang akan kita lihat dalam tahun-tahun yang akan datang adalah komputer tidak lagi ada dan berubah menjadi alat yang tertanam dimanamana.

c. Di masa depan kita akan menyaksikan bahwa komputer akan lenyap ke dalam peralatan (sederhana) yang bisa ditempatkan dimana saja.

The first person plural we is translated into the first person plural kita in (10b-c). In fact, English has simply one subject pronoun for first person plural, we. Nevertheless, Indonesian distinguishes between inclusive and exclusive. The former means that the hearer is included in the first person plural form and the latter means that the hearer is not included (Morin, 2006).

The first person subject $I$, the possessive pronoun his and the third person subject he in the sentences, "I asked an official how much his ministry was inventing in anti-gravity technology. He didn't get the joke, of course" (Newsweek, July $3 /$ July 10,2006 ) are translated as follows:

(11) a. Saya menanyakan besar jumlah dana yang dialokasikan untuk pengembangan teknologi anti gravitasi. Tentu saja, dia tidak menangkap maksud lulecon tersebut.

b. Saya bertanya kepada seorang pegawai seberapa banyak kementeriannya melakukan investasi dalam teknologi anti magnet. Tentu saja dia tidak memahami lulecon itu.

c. Aku bertanya kepada petugas seberapa besar investasi yang dilakukan oleh kementerian tersebut untuk teknologi anti-gravitasi itu. Tentu saja ia tidak menanggapi ocehanku itu.

The Indonesian first person subject saya (11a-b) or aku (11c) is the translation of the English first person subject $I$. The English possessive pronoun his is translated into an enclitic -nya (11b) in the noun phrase his ministry (kementeriannya). The third person subject he was translated into dia (11a-b) and $i a(11 \mathrm{c})$.

As to support this evidence, Morin (2006) points out that the Indonesian third person subject he has two changeable words with the same meaning ia/dia without distinguishing between masculine and feminine, whereas English has two words he and she, which distinguish a gender. In line with this concept, Fromkin (2000) adds that gender constitutes a grammatical opposition between nouns of different categories such as masculine and feminine.

\section{Tense and Aspect}

In English, present and past tense morphemes occur as suffixes on the verb, while the future tense morpheme occurs as the modal verb will or shall. Aspect is a characteristic of the internal structure of an event described by a verb (an expression), e.g. whether the event is viewed as ongoing or completed, whether it is iterated, whether it has an inherent culmination point, etc (Fromkin, 2000). Oxford Advanced Learner"s Dictionary (2010) defines aspect as the form of a verb that shows, for example, whether the action happens once or repeatedly, is completed or still continuing.

Irmawati \& Rohani (2005) highlight that some of the Indonesian adverbs of time that refer to the past tense are kemarin (yesterday), dua hari yang lalu (two days ago). The adverbs of time are implied in the past form of the source language verb, but Indonesian translation does not recognize a verb change as the effect of such an implication, as indicated in the following example:

He didn't get the joke, of course (Newsweek, July 3/July 10, 2006).

(12) a. Tentu saja, dia tidak menangkap maksud lulecon tersebut.

b. Tentu saja dia tidak memahami lulecon itu.

c Tentu saja ia tidak menanggapi ocehanku itu.

The auxiliary verb didn't in the verb phrase didn't get is translated into the target language present tense form tidak menangkap (12a), tidak memahami (12b) and tidak menanggapi (12c) owing to the absence of its adverb of time that points to the activity in the past. Of course, this challenges translators to translate it as evidenced in the target language sentences (12a-c).

The same case happens to the following sentence, which has no adverbs of time, but the only indicator that identifies its tense is the word form in terms of the verb asked (ask + ed) and linking verb was (is + past tense). Look at the translated versions of this sentence, "I asked an official how much his 


\section{International Journal of Science and Research (IJSR) \\ ISSN (Online): 2319-7064}

Index Copernicus Value (2013): 6.14 | Impact Factor (2014): 5.611

ministry was inventing in anti-gravity technology" (Newsweek, July 3/July 10, 2006), as shown below:

(13) a. Saya menanyakan besar jumlah dana yang dialokasikan untuk pengembangan teknologi anti gravitasi.

b. Saya bertanya kepada seorang pegawai seberapa banyak kementeriannya melakukan investasi dalam teknologi anti magnet.

c. Aku bertanya kepada petugas seberapa besar investasi yang dilakukan oleh kementerian tersebut untuk teknologi anti-gravitasi itu.

The sentences (13a-c) indicate the absence of the adverb of time for the past tense. Consequently, translators should translate the verb asked and the past progressive verb in was inventing into the target language present activities menanyakan (13a) or bertanya (13b-c) and melakukan investasi (13b) or investasi yang dilakukan (13c). The past progressive verb in was inventing is translated into a target language noun pengembangan (26a). The translations of the past progressive was inventing are misleading because they refer to the source language past progressive tense was investing (13a-b), not was inventing (menemukan, menciptakan). The translation (13c) is called a class-shift (Catford, 1965) in which a source language item is translated into a target language item that belongs to a different grammatical class, i.e., a verb in the source language may be translated into a noun in the target language, though, it violates the source language message.

\section{Non-past Tense}

Non-past tense is specifically used in the present tense and future tense. Irmawati \& Rohani. (2005) point out that for activities doing at the moment of speaking, the adverbs of time used are kini/sekarang/saat ini (now, nowadays, at the moment). For activities that will be done in the future, the adverb of time used is akan (will). The detailed examples are described below:

What we'll see in the years to come is computers disappearing into devices being imbedded everywhere (Newsweek, July 3/July 10, 2006).

(14) a. Yang terjadi pada tahun-tahun mendatang adalah hilangnya komputer-komputer yang sekarang ada karena tergantikan dengan sarana-sarana teknologi baru yang dipasang berjaring dan terintegral di berbagai tempat.

b. Apa yang akan kita lihat dalam tahun-tahun yang akan datang adalah komputer tidak lagi ada dan berubah menjadi alat yang tertanam dimana-mana.

c. Di mada depan kita akan menyaksikan bahwa komputer akan lenyap ke dalam peralatan (sederhana) yang bisa ditempatkan dimana saja.

The translation of modal verb ' $l l$ (as an enclitic in the contraction we'll) is translated into a modal verb akan (will) in (14b-c), but it is deleted in (14a). Pay attention to another modal verb will (akan), as described in the following translation:
RFID equipped ID cards will enable locals to access government services everywhere they have a $\mathrm{PC}$ or a PDA (Newsweek, July 3/July 10, 2006).

(15) a RFID dengan dilengkapi kartu ID menjadi sarana transaksi masyarakat di berbagai tempat yang tersedia PC atau PDA untuk mendapatkan pelayanan pemerintah.

b. RFID yang dilengkapi dengan kartu ID akan memungkinkan penduduk untuk mengakses layanan pemerintah dimanapun mereka memiliki PC atau PDA.

c. RFID dilengkapi kartu identitas akan memungkinkan penduduk lokal mengakses layanan publik dari dengan menggunakan sebuah PC atau PDA PDA.

The modal verb will is translated into the modal verb akan (15b-c), but it is deleted in (15a) that makes the translation lost in the target language culture.

\section{Voice}

Voice in English grammar refers to the active or passive use of a verb. The active voice is used in making a straightforward statement about an action; that is, the doer of the action in the grammatical subject, and the receiver of the action is the grammatical object (Frank, 1972). Chandra (1994) as quoted in (Wuryantoro, 2005) emphasizes that passive voice is a form of verb, which shows whether its subject is the doer of the action, or something is done to it. Passive voice refers to the sufferer or receiver of the action.

There are three sorts of voice in this sub-chapter: (1) the source language active voice, which is translated into the target language active voice; (2) the source language active voice, which is translated into the target language passive voice; and (3) the source language passive voice, which is translated into the target language passive voice. The first category of voice is indicated in the example below:

Sensors in streetlights will track cars (Newsweek, July 3/July 10, 2006).

(16)a. Alat-alat sensor yang disatukan dengan lampu-lampu jalan raya akan mendeteksi semua kendaraan.

b. Sensor di lampu jalan akan menuntun mobil-mobil.

c. Sensor-sensor yang ditempatkan di lampu jalanan melacak kendaraan.

The source language transitive verb track is translated into the target language active voice mendeteksi (16a), menuntun (16b), and melacak (16c). What to consider is that the target language different verbs do not influence the source language message conveyed through the transitive verb tack that means (1) mengikuti jalan atau jejak and (2) membawa.

The second category of voice is the source language active voice, which is translated into the target language passive voice, as shown in the following translation example:

...the refrigerator back home need replenishing (Newsweek, July 3/July 10, 2006). 


\section{International Journal of Science and Research (IJSR) \\ ISSN (Online): 2319-7064}

Index Copernicus Value (2013): 6.14 | Impact Factor (2014): 5.611

(17) a...kulkas di rumah perlu diisi lagi.

b...kulkas perlu diisi lagi.

c...kulkas di rumah butuh diisi lagi.

The English active voice replenishing (mengisi lagi) in the sentence above is translated into Indonesian passive voice diisi lagi (be needed replenishing). This shift is acceptable and natural in English-Indonesian translation. The third category is the source language passive voice, which is translated into the target language passive voice, as evidenced in the example below:

Cash won "et be needed (Newsweek, July 3/July 10, 2006).

(18) a. Uang tunai tidak akan dibutuhkan lagi.

b. Uang tunai tidak akan dibutuhkan.

c. Uang tunai tak dibutuhkan lagi.

In this example, the source language passive voice is translated into the target language passive voice dibutuhkan (be needed). The passive voice here is formed by the prefix verb - suffix combination namely prefix $-d i+$ verb + suffix $-k a n$. The forms of the translated target language sentences are different, but the source language message conveyed is intelligible.

\section{Semantic Equivalence}

This sub-chapter mainly discusses semantic equivalence. Nida (1964) as quoted in Central Institute of Indian Languages (2006) defines that semantic equivalence is content-oriented by considering a target text in terms of intra-linguistic criteria including grammatical and semantic features, extra-linguistic ones like situation, subject field, target language readers, culture, etc. All these features are put in the context of the source language message conveyed to produce an acceptable translation. As content is indispensable, translators need to express the message in the dynamic way through which language forms are no longer restricted in communicating the message. The contribution of semantic equivalence to the field of translation can be seen in the following example:

This is an important point (Newsweek, July 3/July 10, 2006).

(19) a. Ini tentu hal penting lain yang dicermati pula.

b. Ini merupakan satu hal penting.

c. Ini memang penting untuk dipikirkan.

As shown in this simple sentence, semantic equivalence indicates in the use of the modifier this (deictic in a grammatical system) which is regarded as an equivalent modifier through the translation of the term into ini (19 a-c). Nonetheless, the semantic equivalence in (19 a-c) occurs within a noun phrase an important point (satu hal penting) in (33 b); within words such as penting (19 a \& c) and most of all within the content. The three translations (19 a-c) correspond to the single source language sentence semantically.

The translation in (19) is content-oriented because of two reasons. First, the replacement of the source language grammar with the target language grammar does not influence the message conveyed. This grammatical change is subject to the change of meaning. However, since the language used in this text is for media, such a change is acceptable as long as the source language message is clearly communicated. Second, the first and the third translators translated the source language sentence freely involving the omissions and additions of words. This automatically makes the target language sentences longer and idiomatical in proportion of the forms, but the meaning expressed refers to the same source language message.

In brief, the root point in the source language text "This is an important point" is in the final position, but it is put in the beginning or in the initial position in the target language texts. Considering that fact, the sentence (19 b), for example, is called word-for-word translation but it is categorized as a semantic equivalence viewing from the meaning communicated equivalently. On the contrary, there to be found a lexical change or an adaptation in (19 a \& c). A great deal of adaptation in this example is called dynamic equivalence that is applied in context-bound or communicative translation, but it caters for a semantic equivalence.

The semantic equivalence is not only influenced by the context-bound or communicative translation, but also a morphosyntax (that emphasizes inflections and paradigms). The source language plural noun misunderstandings, for example, has a morphosyntactic construction composed of an inflection $-S$ added to the singular noun "misunderstanding". It can be said that misunderstanding and misunderstandings are the same class of word. Both of them are nouns that refer to the same concept (a failure to understand something in a correct way) but they are different in number. The creation of a semantic equivalence in this context implies the intra-system shift (Catford, 1965) in which the plural noun misunderstandings can be translated into a target language singular noun kesalahpahaman (misunderstanding) or a plural form using a plural marker banyak (a lot of, many) in the phrase banyak kesalahpahaman (a lot of misunderstandings).

Words that contain more than one morphemes (including those composed of an inflection $-s$ ) are translated differently. For example, nouns such as word-s, and sensor-s are translated into kata-kata, alat-alat sensor or sensorsensor using a reduplication and a hyphen (-) as the boundary. Words composed of the inflection -less such as wire-less and seam-less are translated differently as wireless (a loan word) meaning tanpa kabel and tanpa kelim (seamless).

Words composed of affix -ment such as govern-ment is translated by attaching an affix peN- and -an to the stem perintah (to govern) that forms the noun pemerintahan or pemerintah. The phoneme $/ \mathrm{N} /$ in the morpheme $p e N$ - is changed into the phoneme $/ \mathrm{m} /$ if the root that follows is initiated by consonants $\mathrm{p}, \mathrm{b}$, and $\mathrm{f}$ (Ramlan, 2001) in perintah converting into pemerintahan or pemerintah (government). This noun consists of two morphemes namely peN-an, and the verb perintah. 


\section{International Journal of Science and Research (IJSR) \\ ISSN (Online): 2319-7064}

Index Copernicus Value (2013): 6.14 | Impact Factor (2014): 5.611

Words formed the inflection -ly such as frequent-ly and efficient-ly can be translated into the target language adverb seringkali or sering, and translating the adverb of manner efficiently with the target language adverb secara efisien (in an efficient manner) is acceptable semantically. Whatever the forms are, meaning is the important concern of a semantic equivalence.

Words ended with morphemes -s, -less, -ment, and -ly are translated differently. The words such as cars (mobil-mobil), cards (kartu-kartu), and words (kata-kata) are translated using a plural reduplication in the target language. Nevertheless, the term developers is translated into the target language using a collective plural marker para in para pengembang (developers). The adjective wireless is translated using the prefix nir- (that means not, less, without) attaching to the noun kabel (wire) to form the term nirkabel or tanpa kabel (wireless).

\section{Conclusion}

The diction of equivalent words is obviously influenced by the need to focus on accuracy and clarity of the message transferred from the source text into the target text. This conveyage of message is mainly characterized by three domains. First, the choice of lexical words in the target text correlates the meaning of the source text. Second, the choice of certain words in the target text distorts the meaning of the source text. Third, the translatores competence is important to treat neologisms and polisemous words.

As equivalence is difficult to deal with, the availability of bilingual dictionaries, (English-Indonesian) is needed in that they provide direct equivalent words. However, the translatores intervention in determining or interpreting the contextual use of words is slightly essential including the attempt to consult monolingual dictionaries (EnglishEnglish) since certain words are poorly written or even unavailable in the bilingual dictionaries.

In terms of lexical equivalences, the forms and meanings of words are different, but a change of forms, as a direct effect of translation, influences the meanings and the naturalness of the target language. The acceptable meanings of certain words depend on transliteration, reduplication and intrasystem shifts.

In contrast, the omissions or deletions of open-class categories of lexicons in the target language make the source language message lost, misleading or even ambiguous resulting in inevitable non-equivalences. In addition, lexicons that contain polisemous meanings are translated optionally based on the acceptability and naturalness of the target language. The acceptability and naturalness of translation is also concerned with equivalence treatment involving linguistic and extra-linguistic features. By that reason, translation becomes a more and more important means of enhancing linguistic and extra-linguistic understanding within the source and target texts.

Polisemous words in the source language are translated ambiguously into the target language words that mismatch the original message. The additions of words and the effect of descriptive phrases (omnipotent computer, ubiquitous computing, u-technology, etc.) in the target language sentences also indicate the violation of source language message within the lexical items.

The important aspects to consider in grammatical equivalence are number, gender, person, tense, aspect, voice and some of the closed-class categories such as articles and pronouns. The source language singular and plural markers that identify numbers depend on the context of the source text. The indefinite and definite articles such $a$, $a n$, and the are translated or untranslated because they are optional in nature. The translations of plural and singular nouns are influenced by intra-system shifts in which some source language plural nouns are translated into the target language singular nouns and vice versa.

Semantic equivalence is content-based, so the content of the source language text should be translated into the target language text semantically. If the content of the target language does not match the source language, the meaning conveyed is not clear-cut; the accuracy of the words makes the translation weird as it is not suited to the semantic elements of source language.

\section{Acknowledgement}

This research article is partially taken from my master thesis. I am indebted to Dr. J. Bismoko, my former thesis advisor at the Graduate Program in English Language Studies of Universitas Sanata Dharma Yogyakarta, Indonesia, whose motivation and advice helped me accomplish this research.

\section{References}

[1] Baker, Mona. 1992. In other Words a Course Book on Translation. London: Routledge.

[2] Bassnett, Susan. 1991. Translation Studies. London: Routledge, New Fetter Lane.

[3] Campbell, Susan. 1998. Translation into the Second Language. London: Addison Wesley Longman Ltd.

[4] Catford, C. J. 1965. A Linguistic Theory of Translation. Oxford: Oxford University Press.

[5] Central Institute of Indian Languages, Mysore National Book Trust, New Delhi. About Translation. Retrieved from http://www.anukriti.net/translation.htm September $8,2006$.

[6] Duff, Alan. 1998. Translation. Oxford: Oxford University Press.

[7] Echols, John M. and Shadily, Hassan. 1990. Kamus Indonesia Inggris [An Indonesian-English Dictionary]. Jakarta: Penerbit PT Gramedia.

[8] 1990. Kamus Inggris Indonesia [An English-Indonesian Dictionary]. Jakarta: Penerbit P.T. Gramedia.

[9] Frank, Marcella. 1972. Modern English A Practical Reference Guide. New Jersey: Prentice-Hall, Inc.

[10] Fromkin, A. Victoria. 2000. Linguistics An Introduction to Linguistic Theory. Massachusetts: Blackwell Publishing Ltd.

[11] Hatim, Basil and Munday, Jeremy. 2004. Translation An Advanced Resource Book. London: Routledge. 


\section{International Journal of Science and Research (IJSR) \\ ISSN (Online): 2319-7064}

Index Copernicus Value (2013): 6.14 | Impact Factor (2014): 5.611

[12] Hewson, Lance and Martin, Jacky. 1991. Redefining Translation The Variational Approach. London: Routledge.

[13] Hornby, A.S. 2010. Oxford Advanced Learner's Dictionary of Current English. New York: Oxford University Press.

[14] Irmawati, Yunita and Rohani. 2005. Grammatical Equivalence in the Indonesian Translation of J.K. Rowling's Novel "Harry Potter and the Chamber of Secrets." A Paper Presented in INTERNATIONAL CONFERENCE ON TRANSLATION: Translation, Discourse, and Culture. English Department Faculty of Letters and Fine Arts Graduate Program in Translation, Sebelas Maret University of Surakarta.

[15] Jacob, J. Haruna. 2002. African Writers as Practicing Translators: The Case of Ahmadou Kourouma. Translation Journal. Retrieved from http://accurapid.com/journal/22kourouma.htm January 11, 2006.

[16]Larson, Mildred L. 1984. Meaning-based Translation: A Guide to Cross-language Equivalence. Boston: University Press of America, Inc.

[17]Leonardi, Vanessa. 2006. Equivalence in Translation: Between Myth and Reality. Translation Journal. Retrieved

from http://accurapid.com/journal/14equiv.htm October 20, 2005.

[18] Ma mur, Ilzamudin. 2005. Some Potential Problems in Translating "Islamic Studies Texts" from Indonesian into English. A Paper Presented in INTERNATIONAL CONFERENCE ON TRANSLATION: Translation, Discourse, and Culture. English Department Faculty of Letters and Fine Arts Graduate Program in Translation, Sebelas Maret University of Surakarta.

[19] Morin, Izak. 2006. Translating Pronouns and Proper Names: Indonesian versus English. Translation Journal. Retrieved

from http://accurapid.com/journal/35pronouns.htm September 7, 2007.

[20]Nababan, M., 2005. Described Process in Relation to Observed Performance and Assessed Product. A Paper Presented in INTERNATIONAL CONFERENCE ON TRANSLATION: Translation, Discourse, and Culture. English Department Faculty of Letters and Fine Arts Graduate Program in Translation, Sebelas.

[21] Newsweek (July 3/July 10, 2006) A Technology only A Geek Could Love by Christian Caryl.

[22] Ramlan, M. 2001. Ilmu Bahasa Indonesia Morfologi Suatu Tinjauan Deskriptif [Indonesian Linguistics Morphology A Descriptive Review]. Yogyakarta: Penerbit C.V. Karyono.

[23] Thriveni, C. 2002. Cultural Elements in Translation The Indian Perspective. Translation Journal. Retrieved from http//accurapid.com/journal/19culture.htm January 17, 2006.

[24] Wuryantoro, Aris. 2005. A Translation Study of English Passive Voice into Indonesian in Nathaniel Hawthorne's The Scarlet Letter. A Paper Presented in INTERNATIONAL CONFERENCE ON TRANSLATION: Translation, Discourse, and Culture. English Department Faculty of Letters and Fine Arts Graduate Program in Translation, Sebelas Maret University of Surakarta.
[25]Zaky, M. Magdy. 2001. Translation and Language Varieties. Translation Journal. Retrieved from http//accurapid.com/journal/17theory.htm January 10, 2006.

\section{Author Profile}

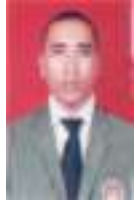

Anselmus Sudirman teaches courses in translating and interpreting, writing and English for accountancy at Universitas Sarjanawiyata Tamansiswa (UST) Yogyakarta, Indonesia where he obtained his undergraduate degree (S.Pd.) from the English Education Department in 2003. He earned his master degree (M.Hum.) in English Language Teaching from Universitas Sanata Dharma (USD) Yogyakarta, Indonesia in 2007. He also edits papers and journals of undergraduate and master students. His scholarly work includes Developing Logical Divisions of Ideas in University Students' Expository Essays (International Journal of Science and Research, Volume 4 Issue 11, November 2015), Teaching Speaking: How to Develop University Students Communicative Competence published by Jurnal Wacana Akademika Vol. 3, Number 8, July 2010, Pentingnya Strategistrategi Menulis untuk Meningkatkan Kemampuan Menulis Mahasiswa [The Importance of Writing Strategies to Improve University Students ${ }^{\text {ee }}$ Writing Competence] published by Jurnal Wacana Akademika Vol. 3, Number 8, July 2011, Optimizing Students' Competence in Writing Weekly Journals (the unpublished research in 2013), Curiosity on Paragraph Writing (a book published in 2014), and The Impact of Revision Strategies on University Students' Writing Competence (a research conducted in 2015). His research interest is English language teaching for university students. 